\title{
OBSERVATIONS ON THE LUMINESCENCE OF PENNATULA PHOSPHOREA, WITH A NOTE ON THE LUMINESCENCE OF VIRGULARIA MIRABILIS
}

\author{
By J. A. C. Nicol \\ The Plymouth Laboratory \\ (Text-figs. I-8)
}

Pennatula phosphorea Linn. is a well-known luminescent animal, which was studied by that pioneer investigator, Panceri (I87I, I872a, b). He found that the animal luminesces when excited, and that the light emanates from the zooids. From the region stimulated luminous waves proceed, with measurable velocity, to the extremities of the animal. Since waves can be initiated in either direction, up or down the colony, it follows that the transmission system is non-polarized. Recent studies on other species of pennatulids have shown that luminescence is under control of a nerve net (Nicol, I955 a, b, $c$; Davenport \& Nicol, 1956). Harvey's book on Bioluminescence (1952) gives a review of pertinent literature, plus a bibliography.

In the present study, the luminescent responses of $P$. phosphorea have been analysed by means of photoelectric recording, with special attention to the flashes of individual zooids. Spectral emission has been determined, and estimates made of the intensity of the luminescence of $P$. phosphorea and Virgularia mirabilis.

\section{MATERIAL AND METHODS}

Specimens of Pennatula phosphorea Linn. and Virgularia mirabilis O. F. Müll. were obtained in the otter trawl I5 miles south of Penmarch light, position $47^{\circ} 32^{\prime}-35^{\prime} \mathrm{N}$., $4^{\circ} \mathrm{II}^{\prime}-12^{\prime} \mathrm{W}$., depth $90 \mathrm{~m}$. These were examined in the ship's laboratory at sea (R. V. 'Sarsia') or brought back to the Plymouth Laboratory.

Luminescence was recorded with photomultiplier tubes, E.M.I. types nos. 6685 and 6095 B, connected to double-beam C.R.O.'s containing DC amplifiers. Oscilloscope deflexions were photographed on moving paper or stationary film. Spectral emission and radiant fluxes were determined with photomultiplier type no. 6685, the spectral sensitivity of which is given elsewhere (Nicol I958a, fig. $2 \mathrm{~A}$ ). For the former measurements spectral filters were used, incorporated in a disc (no. II) and described in table I of another paper (Nicol 1958c). The methods of calculation are described in earlier papers (Nicol I958 $a, b$ ). 


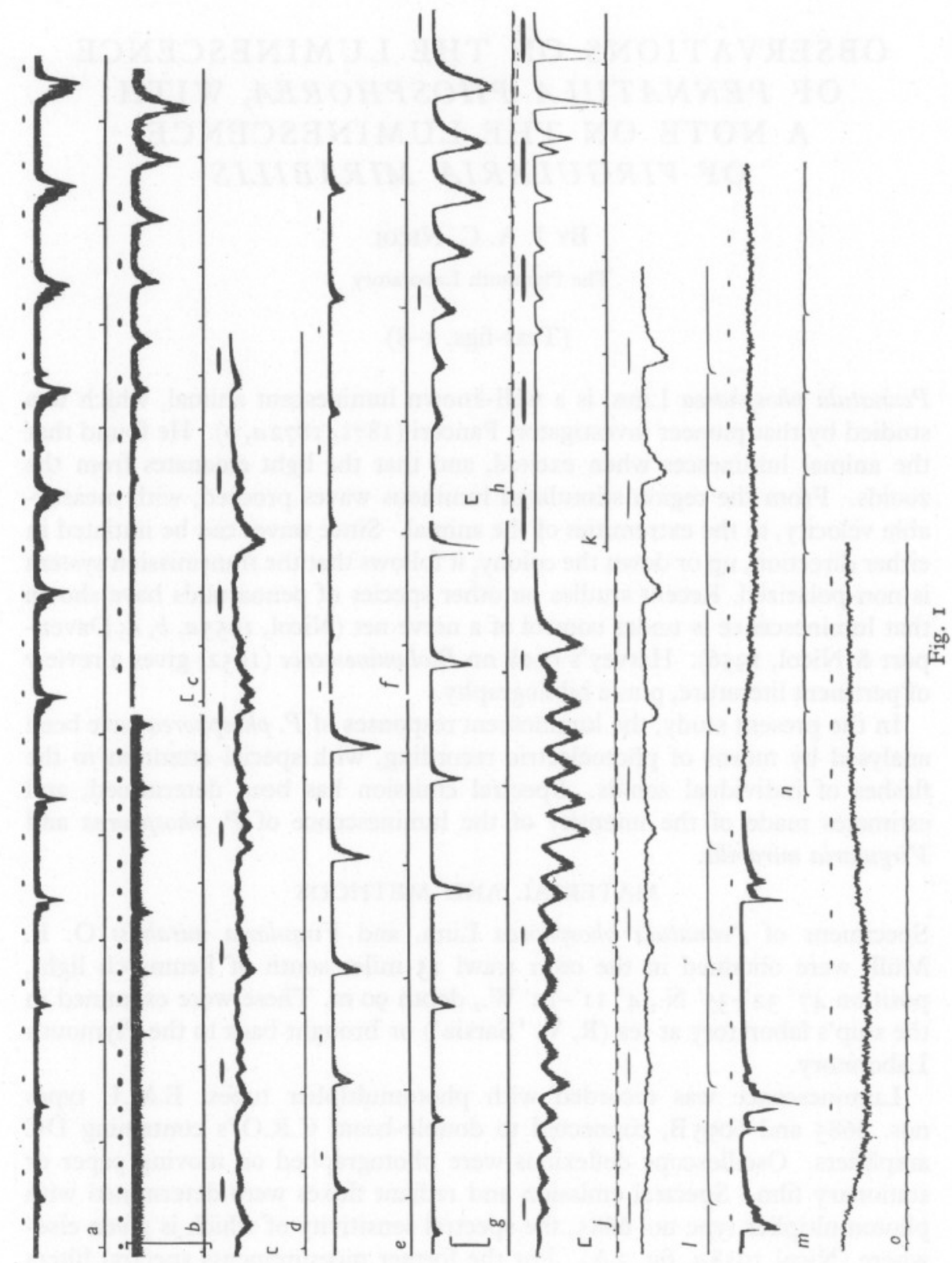


Electrical stimuli were condenser shocks or square wave pulses, applied through Ag or Pt electrodes.

The observations which follow pertain to the autozooids of Pennatula phosphorea, unless indicated to the contrary.

Temperatures at which observations were made ranged from $18^{\circ}$ to $20 \cdot 8^{\circ} \mathrm{C}$.

\section{OBSERVATIONS}

Both Pennatula and Virgularia are elongated sea pens, having a feather-like shape. There is a basal stalk or peduncle, from which arises the distal rachis. The latter has a central shaft, forming a support for a series of leaves on either side. The leaves of the rachis bear numerous autozooids, whereas the back of the shaft is covered with siphonozooids. Virgularia is long and whip-like compared with Pennatula.

When disturbed, Pennatula contracts; when left quiet, it takes in water and gradually swells. Observations were made on rested specimens, that had not been disturbed for an hour or more.

Light is emitted by the zooids (both autozooids and siphonozooids) and when the animal is excited, luminescent waves run over the length of the rachis. With persistent and repeated stimulation, the whole rachidial surface becomes aglow with a scintillating and shifting pattern of luminous points. The response is quickly fatigued, and time is required for recovery.

\section{ELECTRICAL STIMULATION}

Under repetitive electrical stimulation Pennatula responds with luminous waves which run over the surface of the colony from the region of the electrodes (Fig. I $a$ ). Usually a response appears after the first shock, sometimes after the second or third shock. At slow frequencies (intervals > I sec), there

\section{Legend to Fig. I}

Fig. I. Oscilloscope recordings of the luminous flashes of sea pens. Time scale above each record, $\mathrm{I} / \mathrm{sec}$; downward deflexion of middle trace represents luminous response; pips on lower line, if any, are electrical stimuli. Photographs (positives) made on moving paper. (a) Pennatula phosphorea. Recording of transmitted waves from autozooids of whole animal. Burst of $\mathrm{I} 2$ shocks at $\mathrm{I} / 2 \mathrm{sec}$. Temp. $18 \cdot 5^{\circ} \mathrm{C}$. $(b, c, d)$ Pennatula. Responses of siphonozooids in the intact animal to various rates of stimulation $(\mathrm{I} / 2 \mathrm{sec}, \mathrm{I} / \mathrm{sec}, 90 / \mathrm{min}$, respectively). $d$ is latter part of a longer record, beginning with the 13 th pulse, and shows much flickering and afterdischarge. Relative amplification given by height of vertical lines. Temp. $20^{\circ} \mathrm{C}$. $(e, f)$ Flashes of an isolated autozooid of Pennatula, showing fatigue. The autozooid was stimulated with burst of ro shocks (I/sec), 2 min interval between bursts. $e$, 2nd burst; $f, 7$ th burst. Last 5 shocks only shown. Temp. $20 \cdot 8^{\circ} \mathrm{C}$. $(g, h, j)$ Responses of an isolated autozooid of Pennatula to electrical stimulation at various frequencies. $g$, burst at $\mathrm{I} / \mathrm{sec}$, last 7 pulses of $\mathrm{I} 4 ; h, 4 / \mathrm{sec}$, last 8 pulses of $12 ; j, 9 / \mathrm{sec}$, last 20 pulses of 24 . Relative amplification shown by vertical lines. Temp. $20.8^{\circ} \mathrm{C}$. (k) Isolated autozooid of Pennatula. Burst of pulses at $132 / \mathrm{min}$. Note double flashes. Temp. $20^{\circ} \mathrm{C}$. ( $(l)$ Localized responses of siphonozooids of Pennatula. Burst of shocks at $72 / \mathrm{min}$. Temp. $20^{\circ} \mathrm{C}$. $(\mathrm{m})$ Virgularia mirabilis. Transmitted waves elicited by mechanical stimulation. Temp. $17^{\circ}$ C. $(n, o)$ Virgularia. Bursts of pulses at $36 / \mathrm{min}$ and $3 / \mathrm{sec}$. Low band pass filter. Recording from a stretch about $5 \mathrm{~cm}$ long. Temp. $19^{\circ} \mathrm{C}$. 
is I flash/shock, and successive flashes increase progressively in intensity (Fig. I $a$ ). The response pattern is often rather irregular when stimulus intervals are long (Fig. 2).

At slow frequencies, each response has time to return to base-line, thus excluding summation, or the build-up of flash intensity by one response being superposed on its predecessor. Despite the absence of summation, there is still an increment of flash intensity in consecutive responses, an increment which can be ascribed to facilitation (Fig. I $a$ ) (Pantin, I952). The same patterns of responses are shown by other sea pens, e.g. Renilla and Leioptilus (Nicol, I955 $a, b$; Davenport \& Nicol, 1956).

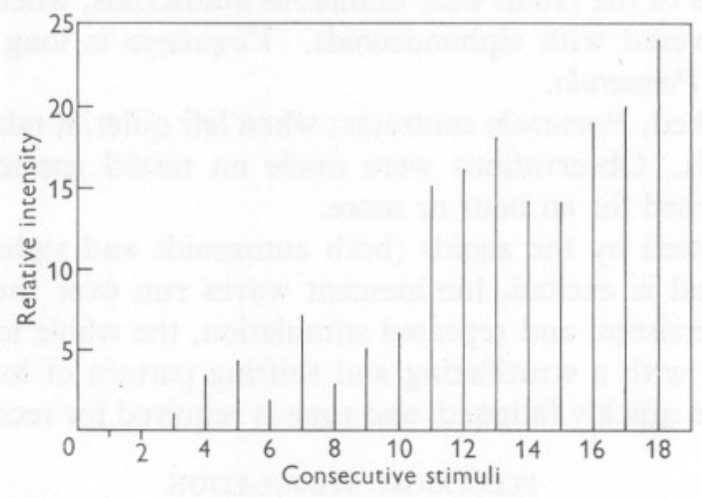

Fig. 2. Histogram showing increase in height of successive flashes of autozooids (Pennatula). Recording from whole animal stimulated with a burst of shocks at $48 / \mathrm{min}$. Temp. $18 \cdot 2^{\circ} \mathrm{C}$.

Facilitation lasts at least I min. An animal was stimulated with bursts of shocks (frequency I-2/sec), the several bursts being separated by intervals of $30 \mathrm{sec}$ or I min. The responses in the second series were brighter than those in the first, and those in the third series brighter still. The enhancing or facilitatory effect is carried over from one period to the next, despite the long intervening intervals of quiescence.

After a burst of impulses, there is often a certain amount of after-discharge, in which several luminous waves continue to arise after stimulation has ceased (cf. Fig. I $d$ ). The luminous waves in a bout of post-stimulatory flashing gradually decrease in frequency and amplitude.

The latency after electrical stimulation was measured as follows. An animal was covered, except for a slit I $\mathrm{cm}$ wide across the body, and the electrodes were placed at this level. The animal was stimulated with a burst of shocks at $\mathrm{I} / \mathrm{sec}$, and responses were recorded at maximal amplification. The mean latent period, in 8 responses, was $0.25 \mathrm{sec}$; variations in measurements were $\pm 0.02 \mathrm{sec}$, and were random.

When recordings were made from a slit lying some distance from the elec- 
trodes, it was found that the latency of the flash increased markedly during a long burst of pulses. Some actual examples are as follows:-

Burst of $\mathrm{I}_{5}$ shocks at $40 / \mathrm{min}$. Latency increased from 0.76 to $\mathrm{I} \cdot 54 \mathrm{sec}$, i.e. an increment of 2 times.

Burst of $\mathrm{I} 8$ shocks at $4 / \mathrm{sec}$. Latency increased from $\mathrm{I} \cdot 2$ to $3 \cdot 2 \mathrm{sec}$, i.e. an increment of 2.7 times

These recordings were made from a $\mathrm{I} \mathrm{cm}$ aperture on the rachis. Since the electrodes were some distance away, the latencies include conduction time to the region from which the flashes were recorded.

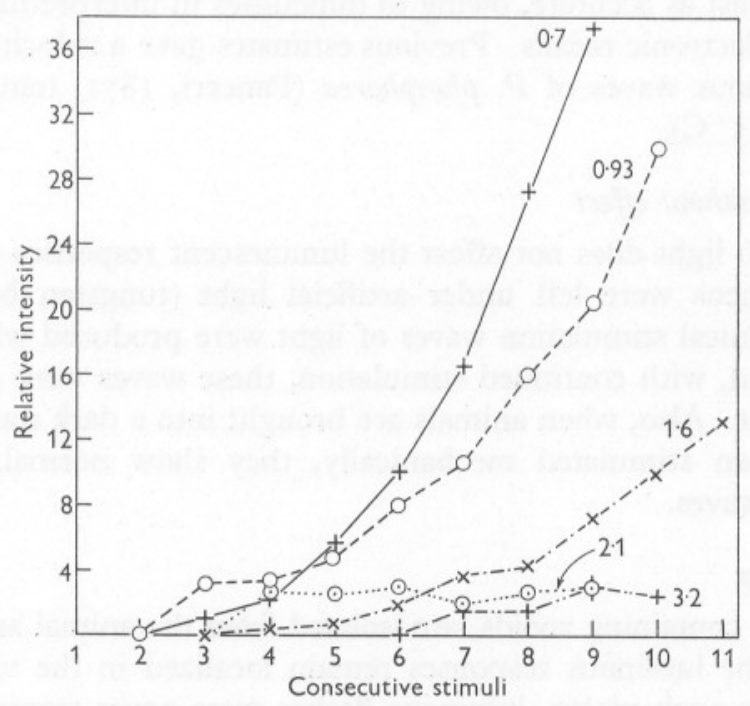

Fig. 3. Facilitation in siphonozooids of Pennatula. Curves showing how the amplitude of consecutive responses increases, and the effect of different frequencies of stimulation. Figures on the curves give the interval between stimuli. Recording of responses of siphonozooids of an intact animal. Temp. $20^{\circ} \mathrm{C}$.

\section{Responses of siphonozooids}

Luminescent responses of the siphonozooids are similar to those of autozooids in the intact animal. Repetitive stimulation evokes luminescent waves that are propagated along the back of the rachidial stem. These increase progressively in intensity, and show the same pattern of facilitation as do the autozooids (Fig. $\mathrm{I} b-d$ ). The rate of facilitatory increment becomes greater as the frequency is raised (Fig. 3). Following prolonged stimulation there is much after-discharge (Fig. $\mathrm{I} d$ ).

\section{Temporal characteristics of flash}

Recordings were made from a slit, $8 \mathrm{~mm}$ wide, extending across a sea pen (Pennatula). The animal was stimulated electrically. Total duration of 
response was $0.7 \mathrm{sec}$; rise to maximum occupied $0.2 \mathrm{sec}$; time to $\frac{1}{2}$ maximum was $0.14 \mathrm{sec}$; decay from maximum was $0.5 \mathrm{sec}$. $\left(\mathrm{I} 8.4^{\circ} \mathrm{C}\right)$. Even in this small field, of course, many autozooids were contributing to the flash.

\section{Conduction velocity}

I made some measurements of conduction velocity, by recording from two slits at a known distance. One or two photomultipliers were used, the latter arrangement being more satisfactory. Average conduction speed was $6.4 \pm \mathrm{I} \cdot 4 \mathrm{~cm} / \mathrm{sec}\left(18^{\circ}-20^{\circ} \mathrm{C}\right)$. A visual estimation of conduction speed is probably at least as accurate, owing to difficulties in interpreting the records obtained by electronic means. Previous estimates gave a velocity of $5 \mathrm{~cm} / \mathrm{sec}$ for the luminous waves of $P$. phosphorea (Panceri, I871, temp. ?; Moore, I926, temp. $\left.15^{\circ} \mathrm{C}\right)$.

\section{Illumination without effect}

Exposure to light does not affect the luminescent responses of Pennatula. Three specimens were left under artificial light (tungsten bulb) for $\frac{1}{2} \mathrm{~h}$. Under mechanical stimulation waves of light were produced which ran over the animal and, with continued stimulation, these waves were succeeded by flickering light. Also, when animals are brought into a dark room from daylight, and then stimulated mechanically, they show normal, transmitted luminescent waves.

\section{Local responses}

When pieces, containing zooids, are isolated from the animal and stimulated electrically, the luminous responses remain localized in the vicinity of the electrodes. In such pieces, luminous flashes were never transmitted, either from autozooid to autozooid, or along a strip of siphonozooids. Preparations which behaved in this way were isolated under $\mathrm{MgCl}_{2}$-anaesthesia, washed in sea water, and allowed long periods for recovery. It would seem that transmission in that part of the nervous system concerned with the luminous response becomes disorganized in an isolated piece of tissue.

\section{Autozooids}

When a pinna is cut off and electrodes are placed on one of the autozooids, only the autozooid immediately under the electrodes responds. No transmission of luminescence is visible in such isolated pieces. The following observations were made on excised autozooids of Pennatula.

With repetitive electrical stimulation an autozooid flashes each time it receives a shock, and consecutive flashes increase progressively in intensity (Figs. I $e, 4,5$ ). This is facilitatory increment. Occasionally an autozooid flashes twice in response to one shock (Fig. I $k$ ). At fast rates of stimulation, the responses run into each other, and fusion is nearly complete at a frequency 
of ro/sec. Continued stimulation leads to fatigue, and the intensities of the flashes decrease. This effect is well seen when an autozooid is stimulated at regular intervals with identical bursts of shocks. In the later series the flashes gradually diminish (Fig. $\mathrm{I} e, f)$.
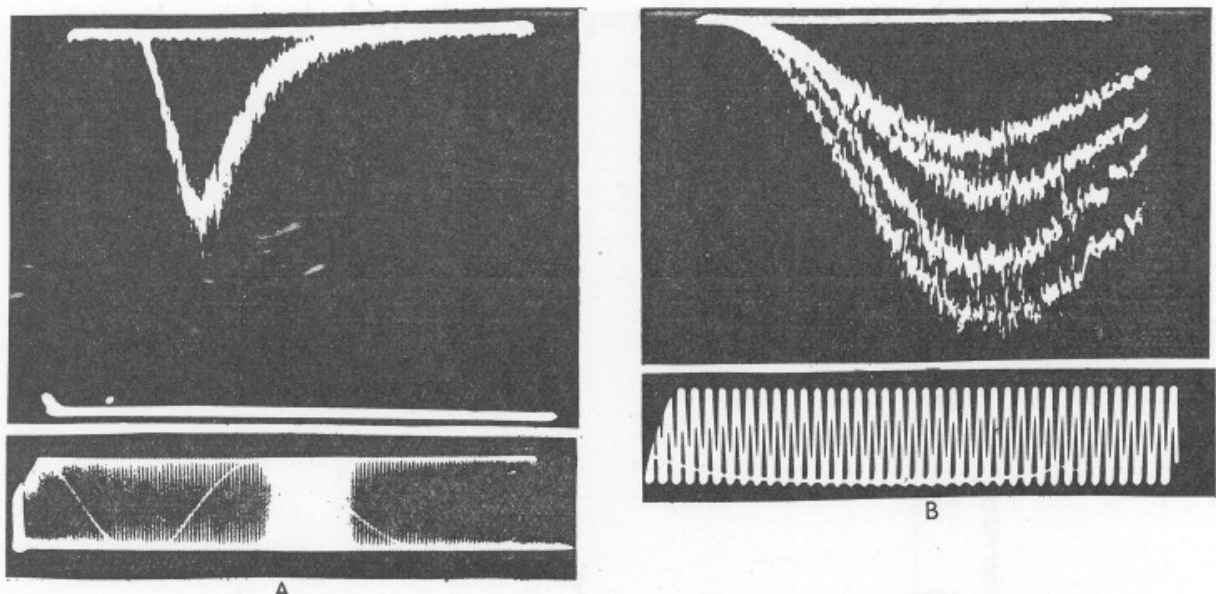

Fig. 4. Responses of an isolated autozooid of Pennatula to a single shock (A), and a burst at $2 / \sec (B)$. Sweeps. Time scale, $50 \sim$. Note facilitation in B. Temp. $20^{\circ} \mathrm{C}$.

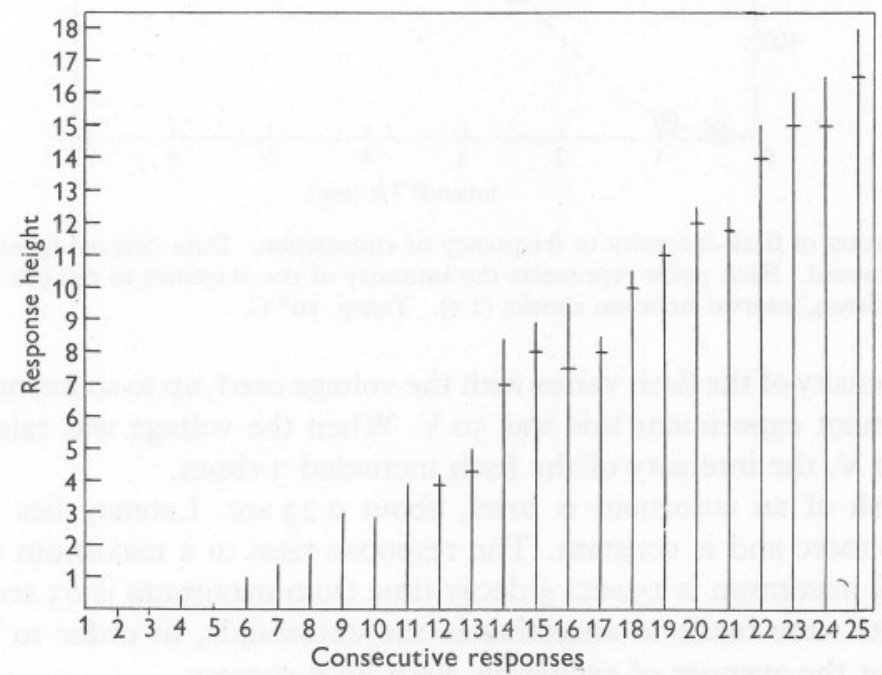

Fig. 5. Histogram showing changes in flash intensity of an isolated autozooid of Pennatula under repetitive electrical stimulation. Bursts of 25 shocks at $39 / \mathrm{min}$. The cross-marks on the vertical lines represent response-height less residual luminescence obtaining at the start of the response. Temp. $20^{\circ} \mathrm{C}$. 
Facilitatory increment becomes more pronounced as the frequency is raised (Figs. I $h-k, 6$ ). At very short intervals (around O.I sec) the process is reversed, the responses become irregular, and amplitudes are smaller than at longer intervals. The following measurements, as an illustration, refer to the responses of an autozooid stimulated with bursts of electrical shocks. The amplitude in each case is that of the response to the roth shock in a burst:

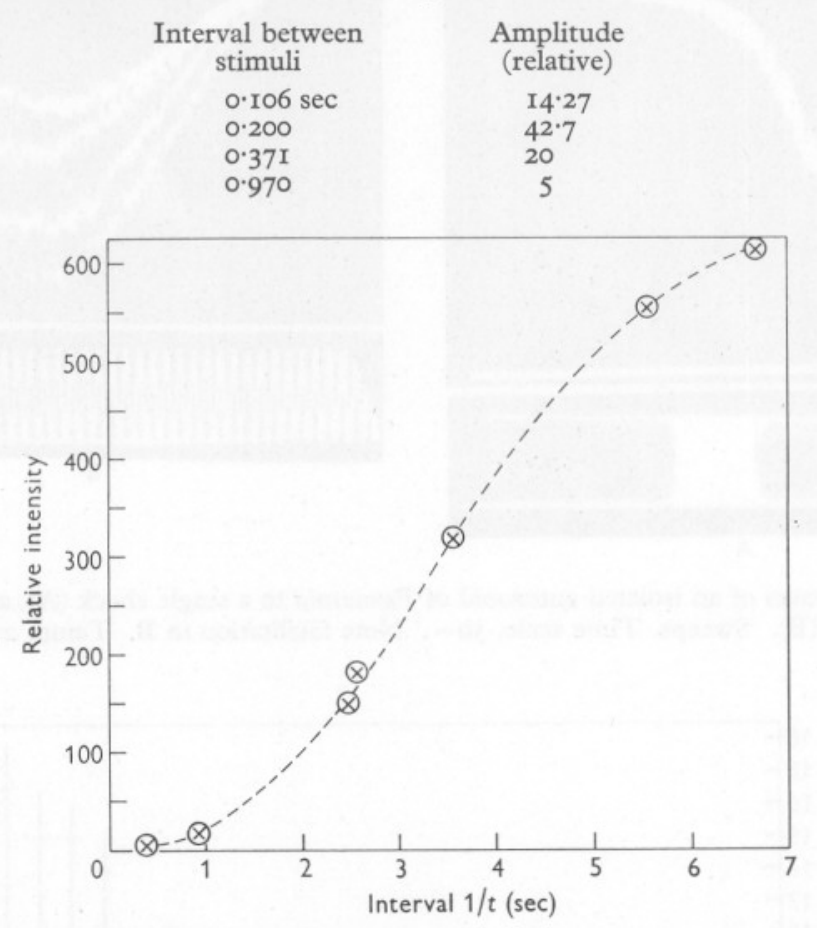

Fig. 6. Relation of flash-intensity to frequency of stimulation. Data derived from flashes of a single autozooid. Each point represents the intensity of the response to the 9 th shock in a series. Abscissae, interval between shocks (I/t). Temp. $20^{\circ} \mathrm{C}$.

The intensity of the flash varies with the voltage used, up to some maximum. In the present experiment this was $50 \mathrm{~V}$. When the voltage was raised from $20 \mathrm{~V}$ to $50 \mathrm{~V}$, the intensity of the flash increased 3 times.

The flash of an autozooid is brief, about $0.23 \mathrm{sec}$. Latency lies between 20 and $30 \mathrm{msec}$ and is constant. The response rises to a maximum in about $39 \mathrm{msec} ; \frac{1}{2}$ maximum is $15 \mathrm{sec} ; \frac{1}{2}$ decay time from maximum is $63 \mathrm{sec}$.

Attempts were made to anaesthetize the autozooids, in order to find out more about the avenues of excitation, with little success.

Autozooids were placed in the following drugs for $3-4 \mathrm{~h}$ : cocaine, $0 . \mathrm{I} \%$; procaine hydrochloride, $0.5 \%$; MS 222 (Sandoz), $0.1 \%$; novocaine, $0.5 \%$; chloretone, $0 \cdot \mathrm{I} \%$; isosmotic $\mathrm{MgCl}_{2}$ : sea water, $\mathrm{I} \cdot \mathrm{I}$. There were very weak 
responses in autozooids poisoned with cocaine and chloretone, none in the others. To a burst of shocks, the autozooid in cocaine gave a series of flashes, $\mathrm{I} /$ stimulus; the first was brightest, and succeeding ones fell off in amplitude. Responses in chloretone were too weak to resolve satisfactorily. All these materials depress excitability too much to yield much information about the luminescent responses.

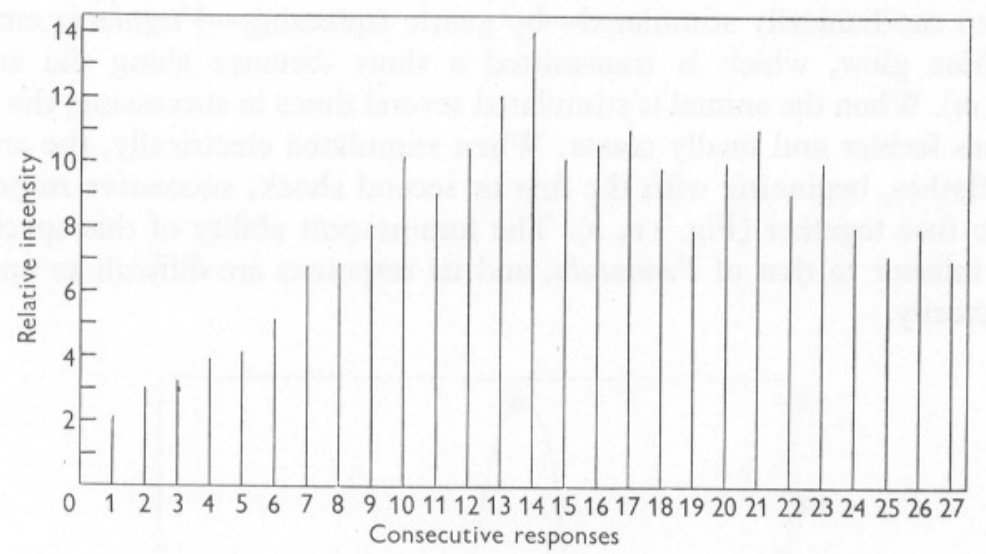

Fig. 7. Change in amplitude of consecutive flashes of siphonozooids (Pennatula). Localized responses from an isolated preparation of siphonozooids. Bursts of 27 shocks at $72 / \mathrm{min}$. Ordinates, relative intensity; abscissae, consecutive responses. Temp. $20^{\circ} \mathrm{C}$.

\section{Siphonozooids}

Isolated preparations of siphonozooids were made by cutting strips from the back of the rachidial stem. Under electrical stimulation luminescent responses are localized to the immediate vicinity of the electrodes. Each shock brings out a flash, the first response is relatively bright and prolonged, slowly reaching maximum; later flashes tend to be briefer, and to increase progressively in amplitude (Fig. 7). The increase in flash intensity occurs at slow rates of stimulation, and suggests that facilitation is operative in these instances (Fig. I $l$ ). In a prolonged burst fatigue sets in, and later flashes decrease in amplitude.

Latency, in localized responses of siphonozooids, is about $50 \mathrm{msec}$. In the first flash of a series, total duration was $>$ I sec; time to maximum was $0.22 \mathrm{sec}$. The I4th flash of a series had a duration of $0.43 \mathrm{sec}$; rise to maximum occupied $0.078 \sec \left(20^{\circ} \mathrm{C}\right)$. There was no obvious increase in latency of consecutive responses. When high rates of stimulation were used, individual flashes could still be resolved at intervals of O.I sec. 


\section{LUMINESCENT RESPONSES OF VIRGULARIA MIRABILIS}

Earlier workers were of the opinion that Virgularia is non-phosphorescent (Hickson, I9I6, p. 154). V. mirabilis, however, is luminescent, but the light is very transitory, and the animal's photogenic ability is easily fatigued. In these respects it resembles Stylatula elongata, belonging to the same family (Virgulariidae) (Davenport \& Nicol, 1956).

When mechanically stimulated-by gentle squeezing-Virgularia emits a faint blue glow, which is transmitted a short distance along the zooids (Fig. I $m$ ). When the animal is stimulated several times in succession, the light becomes feebler and finally ceases. When stimulated electrically, the animal emits flashes, beginning with the first or second shock; successive responses tend to fuse together (Fig. I $n, o$ ). The luminescent ability of this species is much inferior to that of Pennatula, and its responses are difficult to analyse satisfactorily.

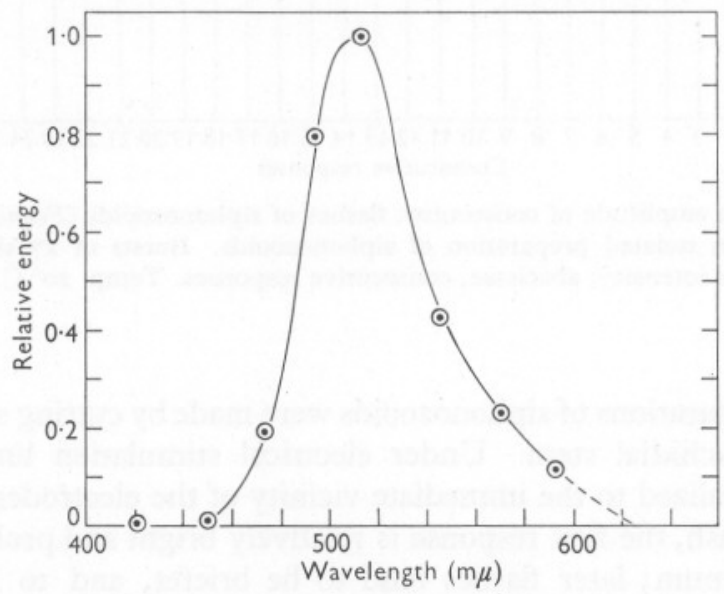

Fig. 8. Relative spectral emission of Pennatula phosphorea.

\section{RELATIVE SPECTRAL EMISSION AND RADIANT FLUX}

Spectral emission in Pennatula phosphorea extends from about 450 to $620 \mathrm{~m} \mu$. Maximal emission occurs at about $5 \mathrm{IO} \mathrm{m} \mu$ (Fig. 8). The light is blue-green in colour.

Using the relative spectral emission curve shown in Fig. 8, estimates have been made of the intensity of light emitted by Pennatula and Virgularia. The light of Virgularia appears blue to the eye, and it is assumed that its spectral composition resembles that of Pennatula. Any difference is unlikely to be sufficient to introduce much error into the estimates of radiant flux.

Pennatula phosphorea. During electrical stimulation, the separate flashes 
increase progressively in intensity, owing to facilitation (p. 554). Flashes, recorded from the whole animal, last $0.4-0.7 \mathrm{sec}$ (Fig. I $a$ ). Radiant flux, in a series of $\mathrm{I} 2$ flashes, increased from $0.84 \times 10^{-6}$ to $6.96 \times 10^{-6} \mu \mathrm{J} / \mathrm{cm}^{2}$ receptor surface at $\mathrm{I} \mathrm{cm}$ distance $\left(\mathrm{I} 8.5^{\circ} \mathrm{C}\right.$.)

Measurements were made of the intensity of light in flashes of isolated autozooids following electrical stimulation. Radiant flux in a single flash varied from $0.096 \times 10^{-9}$ to $62.80 \times 10^{-9} \mu \mathrm{J} / \mathrm{cm}^{2}$ receptor surface at $\mathrm{I} \mathrm{cm}$ distance (temp. $20 \cdot 8^{\circ} \mathrm{C}$ ). The first value refers to the smallest measurable response in a series, the second to a maximal facilitated response.

Virgularia mirabilis. The luminescent response of Virgularia, evoked by mechanical stimulation, lasts about $\mathrm{I}_{2} \frac{1}{2} \mathrm{sec}$. Estimated radiant flux, at $\mathrm{I} \mathrm{cm}$ distance, is $\mathrm{I} \cdot 4 \times \mathrm{IO}^{-4}$ to $\mathrm{I} 2 \times \mathrm{IO}^{-4} \mu \mathrm{W} / \mathrm{cm}^{2}$ receptor surface.

\section{DISCUSSION}

When Pennatula is stimulated waves of light appear which are propagated over the surface of the rachis. The luminescent response is followed by contraction of the animal and expulsion of water. The transmission system responsible for propagation of the luminescent response is presumably nervous; direct proof of this would be best afforded by electric recording. Propagation takes place in any direction (Pennatula and other sea pens), indicating that a non-polarized system is involved. This system could be a neural network possessing two-way synapses, i.e. interneural junctions capable of transmitting with equal facility in either direction. The luminescent response is propagated uniformly and without decrement; that part of the neural network involved, therefore, would appear to partake of the nature of a throughconduction system (cf. Pantin, 1950).

Horridge (1957) has investigated the retractile responses of alcyonarian, zoanthid and madreporarian polyps. In most groups there is extensive coordination over the colony, and in astraeid corals and Tubipora the polyps are linked by a through-conducting system. There appears to be little or no co-ordination of the retractile responses of the polyps of the sea pansy Renilla, according to Parker (I9I9). Peristaltic waves of contraction have been noted in this animal, but these are transmitted at much slower velocities than the wave of luminescence (Parker, I920). Sea pens possibly possess several transmitting systems, each of which is concerned with regulating a particular kind of response, and to test this, or alternative ideas, an analytical study of the various responses of Renilla would be well worth while.

One of the most noteworthy features of the luminescence of sea pens is the progressive increase in the intensity of consecutive responses, as revealed by photoelectric recordings. This increment, termed facilitation, is revealed in localized recording from the intact animal, and in the responses of a single isolated zooid. Now, it is an interesting fact that when a piece of tissue, 
containing several zooids, is removed from Pennatula and is stimulated electrically, only the zooid immediately under the electrodes responds, and no transmission of excitation occurs. Therefore, one may argue, the nerve net is inexcitable in a severed fragment, and the photocytes are responding directly to electrical stimulation. When recordings are made of the flashes of isolated autozooids, it is found that these records show a pattern similar to those recorded from the intact animal. Latency is short, presumably because no transmission time is involved, and facilitation is evident.

In a previous paper dealing with luminescence in Renilla (Nicol, I955 b), evidence was presented that facilitation in that animal involved recruitment of photogenic loci with continued stimulation. Two obvious possibilities relating to facilitation in an isolated autozooid of Pennatula are: (a) individual photocytes have different levels of excitability, some of them responding to a single shock, others requiring many shocks before they respond; continued stimulation, therefore, leads to recruitment of photocytes, and greater light emission; (b) facilitation is an intracellular process involving a progressive increase of excitation in all the photocytes with continued stimulation. The increase in flash-intensity which accompanies a rise of voltage could be explained either way. Intracellular facilitation involving a single cell has been discovered in the flashes of Noctiluca (Nicol, 1958d), which provides an analogy for a similar phenomenon in Pennatula.

Another feature brought out by photo-electric recording is latency. In flashes from a single autozooid the latent period remains constant. But when records of transmitted waves are taken from the intact animal, measured latency from the stimulus to incidence of light emission shows progressive lengthening during a series of pulses. Since transmission through a series of neurones is involved in the latter preparation, but not in the former, it appears that the increase of latent period takes place in the nerve net. Possibly an increase in conduction time is involved, but the records are ambiguous in this respect.

The light of Pennatula phosphorea is blue green in colour. Other animals with similar spectral emission are ctenophores and polynoids (Nicol, I957, I958c). Values for radiant flux, ranging up to $7 \times \mathrm{IO}^{-6} \mu \mathrm{J} / \mathrm{cm}^{2}$ receptor surface at $\mathrm{I} \mathrm{cm}$, are of about the same magnitude as those for flashes of a single polynoid elytrum (Nicol 1958a).

\section{SUMMARY}

The luminescent responses of Pennatula phosphorea and Virgularia mirabilis were investigated by means of photo-electric recording. Pennatula produces luminescent waves which are transmitted over the surface at $6.4 \mathrm{~cm} / \mathrm{sec}$ $\left(20^{\circ} \mathrm{C}\right)$. Facilitation is shown in responses of the whole animal and in responses of isolated autozooids and siphonozooids. Data are given for latency and flashduration. Virgularia is more easily fatigued than Pennatula. Spectral emis- 
sion of Pennatula extends from about 450 to $620 \mathrm{~m} \mu$, with a peak at $510 \mathrm{~m} \mu$. Values for radiant flux are:

$P$ phosphorea, $0.8 \times 10^{-6}$ to $7 \times 10^{-6} \mu \mathrm{J} / \mathrm{cm}^{2}$ receptor surface at $\mathrm{I} \mathrm{cm}$; V. mirabilis, $\mathrm{I} \cdot 4 \times \mathrm{IO}^{-4}$ to $\mathrm{I} 2 \times \mathrm{IO}^{-4} \mu \mathrm{W} / \mathrm{cm}^{2}$ receptor surface at $\mathrm{I} \mathrm{cm}$ (responses of the intact animal). A flash from a single autozooid of Pennatula has an intensity of $0 . \mathrm{I} \times \mathrm{IO}^{-9}$ to $62.8 \times 10^{-9} \mu \mathrm{J} / \mathrm{cm}^{2}$ receptor surface at I cm.

\section{REFERENCES}

DAVENPORT, D. \& Nicol, J. A. C., 1956. Observations on luminescence in sea pens (Pennatulacea). Proc. roy. Soc. B, Vol. I44, pp. 480-96.

Harvey, E. N., I952. Bioluminescence. New York: Academic Press.

Hickson, S. J., I916. The Pennatulacea of the Siboga Expedition: with a general survey of the order. Siboga Exped., Monogr. 14, 265 pp.

HoRRIDGE, G. A., I957. The co-ordination of the protective retraction of coral polyps. Phil. Trans. B, Vol. 240, pp. 495-528.

Moore, A. R., 1926. On the nature of inhibition in Pennatula. Amer. F. Physiol., Vol. 76, pp. II2-15.

Nicol, J. A. C., I955a. Observations on luminescence in Renilla (Pennatulacea). F. exp. Biol., Vol. 32, pp. 299-320.

- $1955 b$. Nervous regulation of luminescence in the sea pansy Renilla köllikeri. f. exp. Biol., Vol. 32, pp. 619-35.

- 1955 c. Physiological control of luminescence in animals. In The Luminescence of Biological Systems (ed. F. H. Johnson). Wash., D.C.: Amer. Ass. Adv. Sci.

- I957. Spectral composition of the light of polynoid worms. F. mar. biol. Ass. U.K., Vol. 36, pp. 529-38.

- 1958a. Luminescence in polynoids. IV. Measurements of light intensity. F. mar. biol. Ass. U.K., Vol. 37, pp. 33-4I.

_ 1958b. Spectral composition of the light of Pholas dactylus. F. mar. biol. Ass. U.K., Vol. 37, pp. 43-7.

- 1958 c. Observations on luminescence in pelagic animals. F. mar. biol. Ass. U.K., Vol. 37, pp. 705-52.

— 1958d. Observations on luminescence in Noctiluca. F. mar. biol. Ass. U.K., Vol. 37 , pp. 535-49.

PANCERI, P., I87I. Gli organi luminosi e la luce delle Pennatule. R.C. Accad. Napoli, Vol. IO, Fasc. I, pp. 204-II.

I872 $a$. The luminous organs and light of the Pennatulae. Quart. F. micr. Sci. Vol. I2, pp. 248-54.

I872b. Etudes sur la phosphorescence des animaux marins. Ann. Sci.nat. (zool.), Sér. 5, T. 16, Art. No. 8, 67 pp.

Pantin, C. F. A., I950. Behaviour patterns in lower invertebrates. Symp. Soc. exp. Biol., No. 4, pp. 175-95.

- 1952. Croonian lecture. The elementary nervous system. Proc. roy. Soc. B, Vol. I40, pp. I47-68.

PARKER, G. H., I919. The organization of Renilla. F. exp. Zool., Vol. 27, pp. 499-507.

1920. Activities of colonial animals. II. Neuromuscular movements and phosphorescence in Renilla. F. exp. Zool., Vol. 31, pp. 475-515. 